\title{
Classification of historical buildings façade's details on the basis of order theory
}

\author{
Ekaterina Vozniak $^{1, *}$, and Andrey Butyrin ${ }^{2}$ \\ ${ }^{1}$ Saint Petersburg State University of Architecture and Civil Engineering (SPSUACE), 2-nd \\ Krasnoarmeiskaya St. 4, 190005 St. Petersburg, Russia \\ ${ }^{2}$ Moscow State University of Civil Engineering, 129337, 26, Yaroslavskoe Shosse, Moscow, Russia
}

\begin{abstract}
On the basis of theoretical works devoted to the classical theory of architecture, classification of details of facades of historical buildings built on the basis of order theory is presented. The main classification features are the location of elements on the facade and the complexity of the form making. The proposed classification allows covering the variety of types of historical elements of facades in a short course, which is important in the training of architects-restorers, as well as architects using order details. The principles of the proposed classification can be used to study the details of buildings of any stylistic architectural period based on classical order architecture.
\end{abstract}

\section{Introduction}

Details of buildings facades are the most important components of architecture, directly determining the image of the architectural structure. Details of facades of historical buildings of the XVII-XIX centuries are the basic elements, the study of which is of great importance not only for the restoration of architectural monuments, but also for the history of architecture in general. Decorative elements of facades are difficult to study because of their diversity. There are many types of details of facades of historical buildings: columns, frames of windows and doors, rusts, cornices, rods, panels, etc. The forms of these elements are different in different style periods and in different regions of construction. Thus, the study of details is complicated by the need to consider the set of elements that changed in different style periods. It is necessary to develop a unified approach to the analysis of order architectural forms, allowing us not only to consider each element separately, but also to cover the entire system of elements on the facade as a whole. At present, there is no classification of architectural elements of historical buildings. This article proposes the systematization of architectural details of facades, the construction of which is based on the classical order system. To do this, it is proposed to proceed from the consideration in the works on the theory of architecture of the XVII-XIX centuries. It is necessary to develop a classification, the principles of which are applicable to the study of details of buildings of any style period based on classical order architecture.

\footnotetext{
*Corresponding author: vozniak65@mail.ru
} 


\section{Materials and methods}

Building architectural details of European buildings of XVII-XIX centuries based on order classical theory [1]. This classical theory is based on treatises by M. Vitruvius, L.-B. Alberti, S. Serlio, J. Vignola, A. Palladio, V. Scamozzi, and others [2, 3, 4]. Fundamental treatise of N.-F. Blondel "Cours d'architecture" [5] published in 1700 contains a description of methods for constructing classical elements and details. This work became the fundamental in the professional training of the architects of the XVIII-XIX centuries. Numerous works devoted to shaping the order elements were issuing out till the beginning of XX century. The works of A.-Ch. D'Aviler, L. Sturm, J.-F. Blondel, M.-A. Laugier, J.-F. Neufforge, P. Letarouilly, J. Buhlmann, A. Brausewetter $[6,7,8,9,10]$ had the most significant impact on the Russian architectural design practice. In Russia in the XIX century, one part of the theory of architecture, which devoted to the shaping of the parts, obtained the name of "theory of architectural forms". The term "theory of architectural forms" is found in the works of N. Sultanov, A. Durov, V. Pyasetsky, and I. B. Mikhalovskiy [11,12,13, 14]. This theory described the construction of the orders, the rules for constructing the frames of portals and doors, gables and attics, balusters and parapets, etc. Principles and rules of "theory of architectural forms" were a basis of professional education of the architects in the XVIII early XX centuries in the Russian Empire. In the Soviet period, the only theorist studying architectural order elements was I. B. Mikhalovskiy [14]. At the beginning of the XX century, under the influence of the ideas of functionalism, the classical theory of architectural forms was criticized, and since then it has been abandoned.

"Theory of architectural forms" included historical information about the appearance and development of architectural order elements, rules of construction and drawing of facade details [15]. "Theory of architectural forms" considered only the details of classicism that arose in the era of Antiquity and the Renaissance. These elements were considered to be the main and form making. All other details and forms (Baroque, Gothic, eclectic, etc.) were not included in the basic course.

In the process of development of the "theory of architectural forms", there was developed a certain order of consideration of the elements of facades, which allowed easier and faster learning the material for all who was studying the theory of architecture. The traditional sequence helped to operate with numerous elements in real design easier. This approach was described in the works of F. and J.-F. Blondels, J. Gibbs, L. Sturm, J.-F. Neufforge, and others. It is repeated in books of A. Krasovsky, A. Durov, N. Sultanov. Each architect demonstrated the fundamental elements in the generally accepted sequence and added the author's elements that were specific to the country and time. The approach of consideration of the elements was formed by the XVIII century. At first, the elements were distributed according to the location on the facade, and then there was consideration of formation of each type from the simplest to the most complex form.

\section{Results}

According to various sources of XVI - early XX centuries, the classification of facade elements of classicism was collected and expanded. There was a graphical table which allowed structuring the system, simplifying perception, and covering the system as a whole (see Fig. 1). The infographic scheme provides information on the fundamental canonical facade elements that are most commonly found in works on the theory of architectural forms. These details were studied by all architects in the XVII - XIX century during professional education. 


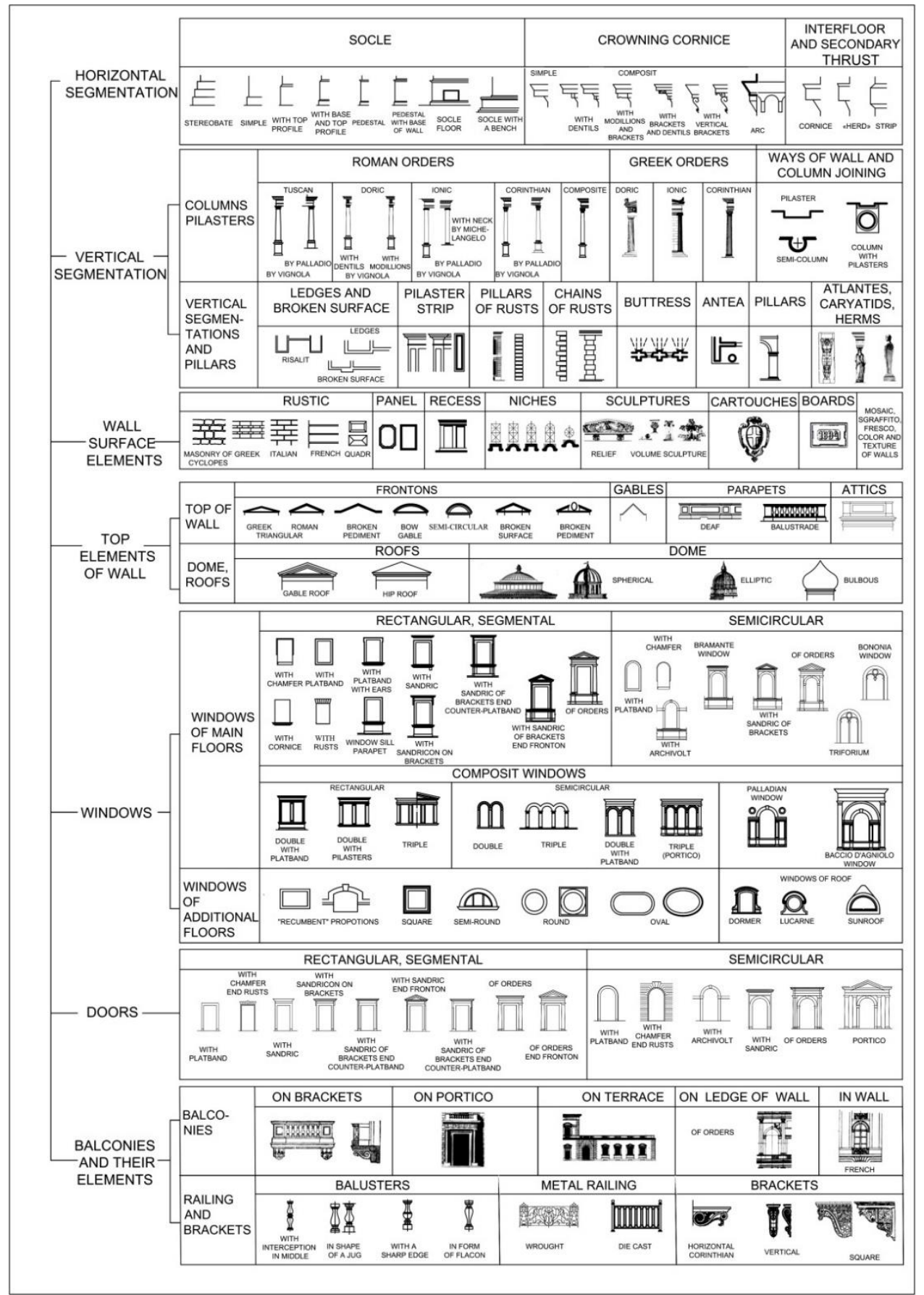

Fig. 1. Summary of classification of details of the facades built on the basis of an order of the classical theory.

The order facade details were subdivided into seven large groups:

- horizontal segmentation of walls;

- vertical segmentation of walls;

- wall surface elements; 
- top element of wall;

- windows;

- doors;

- balconies.

The system of vertical and horizontal articulation of the facade of the building is visually perceived as a whole, but in the classical "theory of architectural forms", the analysis of the construction of vertical and horizontal articulation was made separately. It was believed that "...the domination of the horizontal articulation in the facade gives the impression of solidity and stability of the building; on the contrary, the abundance of vertical articulation gives the facade lightness and upward tendency" [10].

The horizontal articulation of the walls was considered first as determining for the construction of a column order on the facade and the entire facade as a whole. Horizontal articulation included the following elements: socle, crowning cornices, interfloor cornices, window and secondary molding. From the point of view of the classical theory, each element had several types of possible drawing forms. They were considered in a certain traditional sequence. For example, the basic socle could be: stereobate, simple, with top profile, with base and top profile, pedestal, pedestal with base of wall, socle floor, and socle with a bench (Fig. 2). On the example of the basic socle it is seen that the forms become more complicated and gradually approach the order, in this case to the pedestal. THRUST

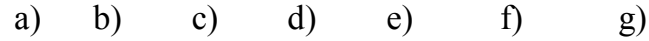

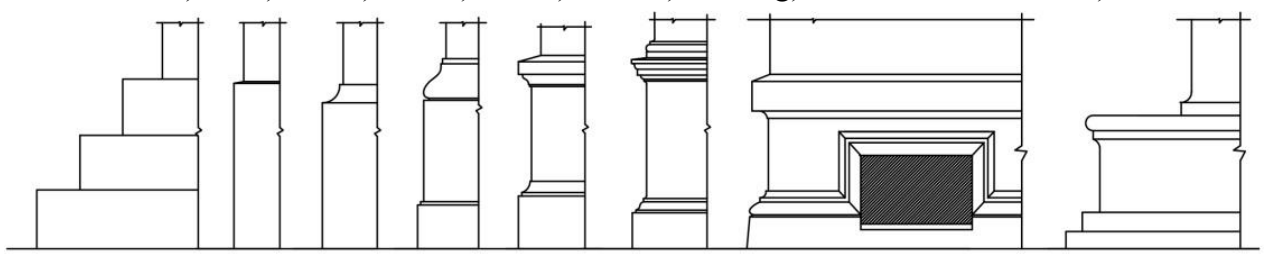

h)

Fig. 2. Classic architectural shapes of the bases: $a$ - stereobate, $b$ - simple, $\mathrm{c}$ - with top profile, $\mathrm{d}-$ with base and top profile, e - pedestal, $\mathrm{f}$ - pedestal with base of wall, $\mathrm{g}$ - socle floor, $\mathrm{h}$ - socle with a bench.

Then there was consideration of the vertical articulation: columns and pillars (roman and greek orders), ledges and broken surface, pillars and chains of rusts, buttress, antea, atlantes, caryatids, herms, etc. The vertical articulations also included columns and pilasters; they were mentioned in particular and in the first place. The importance of the column order for the construction of the entire facade was emphasized. After the vertical and horizontal articulation, there were considered the processing wall surface elements (rustic, panels, niches, sculptures, cartouches, boards, mosaic, sgraffito, fresco, color and texture of walls) and top element of wall (frontons, gables, parapets, attics, domes, etc.). After that we started to analyze the forms and frames of windows and doors. Balconies concluded the consideration. Various additions were also possible, for example, fences, gates, etc.

Thus, it can be seen that at the first level of the classification, elements are grouped by location on the facade, and at the second level, specific types of facade elements are distinguished. Then the forms of each element are considered - from simple to complex. The simplest form, as a rule, was the most utilitarian, and the most developed form included a column order. For example, windows were classified first by their location on the facade (windows of the main and secondary floors), and then by their shapes (rectangular, semi circular, complex, round, oval, etc.), and then by the types of frames - from windows without frames to the order window. Options for framing rectangular windows of the main floors were described in the following order: simple windows (without frames), with frames, with sandriks, order forms of windows (Fig.3). 
a)

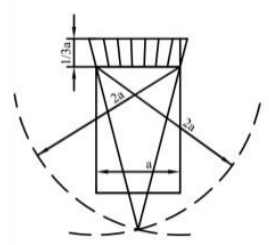

g)

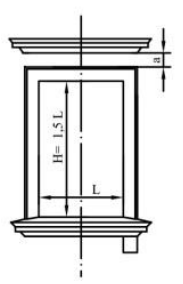

b)

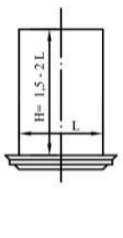

h)

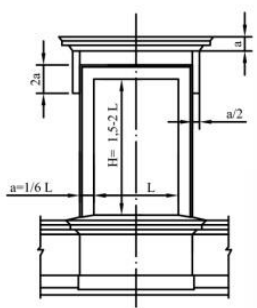

c)

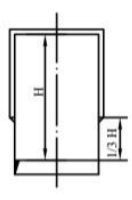

i) d)
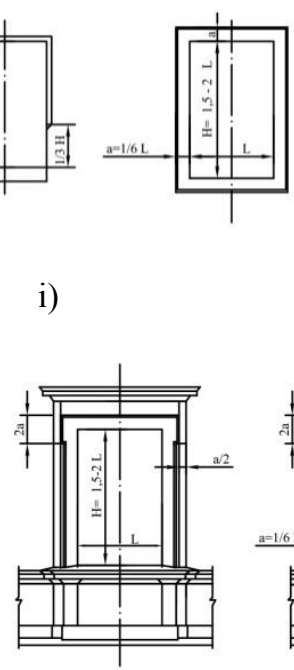

j)

e)
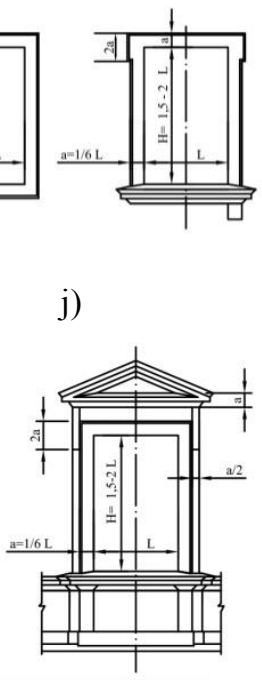

f)

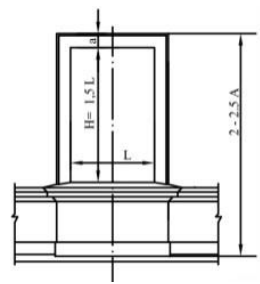

k)

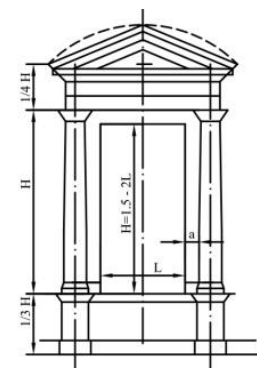

Fig. 3. Classical architectural forms of rectangular windows of the main floors: $a$ - with RUSTS, $b-$ with cornice, $\mathrm{c}$ - with platband with ears, $\mathrm{d}$ - with platband, $\mathrm{e}$ - with platband with ears, $\mathrm{f}-$ window sill window sil, $\mathrm{g}$ - with sandric, $\mathrm{h}$ - with sandric brackets, $\mathrm{i}$ - with sandric brackets end counter-platband, $\mathrm{j}$ - with sandric brackets end fronton, $\mathrm{k}-$ of orders.

\section{Discussion}

The principles of the proposed classification are applicable to architectural details built on the basis of the order theory. It cannot be spread to the architectural details of the styles that existed before the XVI century and later than the beginning of the XX century. But the principles of the proposed classification are quite applicable to the eclectic forms of the late XIX century. It would be interesting to compare the tables and descriptions of the construction of details of specific stylistic historical periods and regions.

\section{Conclusion}

Despite the apparent complexity, this logical and interconnected system was easy to remember by architects. The complex of information helped in the design to keep all the facade elements in the mental field of view, consciously improve them and add new forms.

The given list of elements was not only used in the study of the theory of architectural forms but also to some extent determined the order of the facade design. The facade was built gradually - from the general composition solution, the choice of the order system, then the construction of horizontal and vertical elements, and further in the previously given order.

Thus, the proposed classification allows covering the whole system of historical order facade elements in general and the formation of specific details. Consideration of elements in this sequence allows studying the formation of historical elements within a short course. This is important in the training of architects-restorers, as well as architects using order details. The proposed classification covers the fundamental elements studied in the process of vocational education by all architects in XVIII - XIX century, and allows proceeding to the consideration of elements of specific buildings of specific historical periods and regions. 


\section{References}

1. Architectural theory: from the Renaissance to the present: 89 essays on 117 treatises (Taschen, Köln, 2011)

2. M. Vitruvius, Desyat knig ob arkhitekture (All-Union Academy of Architecture Publ., Moscow, 1936)

3. J.B. Vignola, Pravilo pyati orderov arkhitektury (All-Union Academy of Architecture Publ., Moscow, 1939)

4. A. Palladio, The four books of architecture (Kupfertafen, London, 1738) http://www.erara.ch/zut/content/titleinfo/3982323

5. F. Blondel, Cours d'architecture enseigné dans l'Académie Royale d'Architecture, http://www.e-rara.ch/zut/content/titleinfo/1287114

6. A.-Ch. Aviler, D' Cours d'architecture: qui comprend les Ordres de Vignole, avec des commentaires, les figures \& les descriptions de ses plus beaux bâtimens, \& de ceux de Michel-Ange, http://www.e-rara.ch/zut/content/titleinfo/200

7. L.Ch. L.C. Sturm, Sturms vollständige Anweisung Regierungs-, Land- und Rath-Häuser, wie auch Kauff-Häuser und Börsen starck, bequem und zierlich anzugeben, http://www.e-rara.ch/zut/content/titleinfo/3436152/

8. J.-F. Blondel, Cours d'architecture, ou Traité de la décoration, distribution \& construction des bâtiments, http://www.e-rara.ch/zut/content/titleinfo/103727

9. J.-Fr. Neufforge, Recueil Elementaire d'Architecture, http://www.ub.uni-heidelberg.de

10. A. Brausewetter, K.V. Naumova, Architectural forms of civil buildings (St. Petersburg, 1904)

11. N. Sultanov, Teoriya arkhitekturnykh form (Moscow, 1914)

12. A. Durov, Arkhitekturnye formy. Kamennye, kirpichnye i derevyannye (Moscow, 1904)

13. V.N. Pyasetsky, Architect. 40, 453-455, 41, $463-467$ (1902)

14. I.B. Mikhalovskiy, Teoriya klassicheskikh arkhitekturnykh form (All-Union Academy of Architecture Publ., Moscow, 1937)

15. V. Murgul, N. Vatin, E. Aronova, Applied Mechanics and Materials 635-637, 20292035 (2014), doi:10.4028/www.scientific.net/AMM.635-637.2029

16. A. Ulybin, A. Lanko, N. Vatin, K. Lysnytska, MATEC Web of Conferences 73, (2016), doi:10.1051/matecconf/20167301007 